\title{
A new species of Trichodesmium (Cyanobacteria) from freshwaters, Brazil
}

\author{
Célia L. Sant'Anna ${ }^{1,3}$, Watson A. Gama ${ }^{1}$, Thais G. Silva ${ }^{2}$ \& Armando A.H. Vieira ${ }^{2}$
}

\begin{abstract}
Trichodesmium is a typical planktic genus in which trichomes are disposed either in fascicles or radially in rounded colonies. Based on morphological studies, there are eleven species of Trichodesmium, out of which nine are from marine environments and only two from freshwaters. Trichodesmium is mainly known for its capacity to form blooms and produce toxins in marine tropical and subtropical environments. There is no information about the capacity of the freshwater Trichodesmium species to produce toxins. It was only with molecular studies that the taxonomy of marine Trichodesmium started to be solved. However, up to now, no material has been available for molecular analyses of freshwater species. During the studies of microalgae from São Paulo state, a population resembling Trichodesmium was found in a recreational pond. The analyzed organisms formed fascicles of homocyted and not attenuated trichomes and cells with gas vesicles, a set of features that makes them different from the other freshwater Trichodesmium species. Thus, we have described the species Trichodesmium brasiliense sp. nov. based on material from Brazilian inland water. Also, we have suggested revision of some Brazilian literature citations of $T$. lacustre and their inclusion in the synonym of this new species.
\end{abstract}

Key words: new species, Oscillatoriales, shallow lakes, Trichodesmium lacustre, tropical region.

\section{Resumo}

Trichodesmium é um gênero tipicamente planctônico cujos tricomas estão dispostos em fascículos ou radialmente em colônias. Com base em estudos morfológicos, existem 11 espécies de Trichodesmium descritas, das quais nove são para ambientes marinhos e apenas duas para águas continentais. Este gênero é conhecido principalmente por sua capacidade de formar florações e produzir toxinas em ambientes marinhos tropicais e subtropicais. Contudo, não há informações sobre produção de toxinas por suas espécies de água-doce. Foi apenas com os estudos moleculares que a taxonomia das espécies marinhas começou a ser resolvida. Contudo, até o presente, não há material disponível para a realização de estudos moleculares com as espécies de ambientes continentais. Durantes o estudo das microalgas do Estado de São Paulo, uma população similar a Trichodesmium foi encontrada em uma lagoa utilizada para recreação. Os organismos analisados formavam fascículos compostos por tricomas homocitados e não atenuados, com aerótopos presentes; características que os tornam diferentes de outras espécies de Trichodesmium. Assim, descrevemos a espécie Trichodesmium brasiliense sp. nov. a partir da análise de espécimes de águas continentais brasileiras. Adicionalmente, sugerimos a revisão de algumas citações da literatura brasileira para T. lacustre e inclusão dessas na sinonímia da nova espécie descrita.

Palavras-chave: nova espécie, Oscillatoriales, lagos rasos, Trichodesmium lacustre, regiões tropical/subtropical.

\section{Introduction}

Trichodesmium was originally proposed by Ehrenberg (1830) and later was included in the genus Oscillatoria (Kützing 1843). It was only based on the work of Gomont (1892) that the genus Trichodesmium was definitively considered as a valid generic entity. According to Komárek \& Anagnostidis (2005), Trichodesmium is typically planktic, in that the trichomes are disposed either in fascicles or radially in rounded colonies and are cylindrical or slightly attenuated, straight or curved, rarely coiled, without sheath and always present gas vesicles. Based on morphological studies, Komárek \& Anagnostidis (2005) recognized 11 species of Trichodesmium, out of which nine are from marine environments and only two are from freshwaters.

\footnotetext{
${ }^{1}$ Instituto de Botânica, Lab. Ficologia, Av. Miguel Stéfano 3687, 04301-012, São Paulo, SP, Brazil

${ }^{2}$ Universidade Federal de São Carlos, Depto. Botânica, Rod. Washington Luís s/n, km 235, 13565-905, São Carlos, SP, Brazil

${ }^{3}$ Author for correspondence: celialsant@gmail.com
} 
Trichodesmium is mainly known for its capacity for forming blooms and producing toxins in marine tropical and subtropical environments (Capone et al. 1997; Orcutt et al. 2002; Detoni et al. 2016). According to Suvapepun (1992), the blooms are initially formed in deep layers of the water column and later they accumulate on the water surface forming an extended reddish or yellowish mass. The ability to accumulate on the water surface is due to the big and very resistant gas vesicles of the Trichodesmium genus (Capone et al. 1997).

Trichodesmium species play a very important role in nitrogen fixation and, in some marine environments, they constitute most part of the total biomass. Biomass contributes intensively to nitrogen fixation and, consequently, contributes significantly to the global nitrogen cycle (Carpenter 1983; Capone et al. 1997; Capone et al. 2005).

In relation to toxin production, the marine Trichodesmium species are known as microcystin and saxitoxin producers (Jackson et al. 2001; Shaw et al. 2001; Long \& Carmichael 2003). In the Brazilian literature, there are also records of intoxication induced by Trichodesmium blooms in marine environments (Detoni et al. 2016), but there is no information of the capacity of the freshwater Trichodesmium species to produce toxins.

The taxonomy of marine Trichodesmium started to be really solved only with molecular studies (Orcutt et al. 2002). According to these studies, there are only two groups of marine species: one formed exclusively by Trichodesmium erythraeum Ehrenb. ex Gomont and the other formed by closely related species (Trichodesmium thiebautii Gomont ex Gomont, Trichodesmium tenue Wille, Trichodesmium hildebrandtii Gomont and Katagnymene spiralis Lemmerm.). There is no molecular information about freshwater Trichodesmium but in terms of phylogeny, a great distance between the marine and freshwater species will probably be found on the generic level (Komárek \& Anagnostidis 2005). Unfortunately, up to now there is no material for the necessary molecular analyses of freshwater species.

The two freshwater species, Trichodesmium iwanoffianum Nygaard and Trichodesmium lacustre Kleb., have been poorly studied and rarely cited in the literature. The first is restricted to tropical regions and the second occurs in temperate, tropical and subtropical areas (Komárek \& Anagnostidis 2005). There are few references about freshwater
Trichodesmium in Brazil and all of them refer to T. lacustre (Komárek \& Komárková-Legnerová 2007; Martins et al. 2012). However, the species has been problematic since its description, when Klebahn pointed out its similarity to heterocyst-free Aphanizomenon representatives (Klebahn 1895). Despite its confirmation as a separate taxon and identity, Prescott (1962) also commented that the material he found in freshwater environments in North America may not exactly correspond to $T$. lacustre, although it was the closest species to his material. This puts in evidence that the diversity of continental Trichodesmium species is greater than it has been described so far.

A population similar to Trichodesmium, with homocyted trichomes disposed in fascicles and cells with gas vesicles, was found during studies on microalgae from São Paulo state. The organisms present a set of morphological features that makes them different from the other Trichodesmium species. Thus, based on our results, we are proposing a new species of Trichodesmium from Brazilian inland water.

\section{Material and Methods}

The studied sample was collected with a plankton net $(20 \mu \mathrm{m})$ in a shallow pond used for recreation, coordinates $21^{\circ} 03^{\prime} 302 \mathrm{~S} \& 050^{\circ} 02^{\prime}$ $809 \mathrm{~W}$. The sample was preserved in formaldehyde $4 \%$. The type material is kept in the Herbarium of Institute of Botany, São Paulo, Brazil, under the accession number SP469314. Sample aliquots of analyzed material by Martins et al. (2012) and Komárek \& Komárková-Legnerová (2007) were recovered from Herbaria to compare the population described by these authors with the herein proposed species.

Based on nature material, the morphological study was performed with a Zeiss Axioplan 2 optical microscope and the identification and cell measurements were carried out in 15 individuals. Digital photographs taken with a Zeiss Axiocam MRc digital camera documented the organisms. The observed morphological features were the following: fascicle length and width and cell length, width and length/width rate, presence of gas vesicle and trichome features (attenuation, constriction and form of apical cell). The new species was described according to the International Code of nomenclature for algae, fungi, and plants (McNeill et al. 2012) and the classification system proposed by Komárek et al. (2014) was adopted. 


\section{Results and Discussion}

Trichodesmium brasiliense Sant'Anna et al.

Fig. 1a-j

Synonymous: Trichodesmium lacustre sensu Martins et al. (2012) and Trichodesmium cf. lacustre sensu Komárek \& Komárková-Legnerová (2007).

Thallus microscopic, fasciculate, 70-96 $\mu \mathrm{m}$ wide, 820-868.5 $\mu$ m long, formed by several (6-10) trichomes densely aggregated. Trichomes straight, not attenuated, strongly constricted, without mucilage. Cells elongated or more rarely barrel shaped, with gas vesicles, 4.6-7.1 $\mu \mathrm{m}$ wide, 4.9-7.4 $\mu \mathrm{m}$ long; apical cell hemispheric or elongated.
Holotype: BRAZIL. SÃO PAULO: Zacarias, Prainha do Zacarias, 19.III.2014, T.G. Silva (SP469314).

Habitat: shallow pond, presence of macrophytes (Eichhornia, Salvinia, Egeria and Eleocharis); $\mathrm{pH}$ 7.15 , water temperature $32{ }^{\circ} \mathrm{C}$, dissolved oxygen $3.81 \mathrm{mg} \mathrm{L}^{-1}$; conductivity $0.023 \mathrm{mS} \mathrm{cm}^{-1}$.

Table 1 shows that there are evident morphological differences between the compared species: the studied population presents deeply constricted trichomes and rounded-elongated and isodiametric cells (width/length rate around 1) different from Trichodesmium iwanoffianum, which has short barrel-shaped cells (width/ length rate 2-3.5). As for T. lacustre, the greatest difference is the attenuated trichomes of the

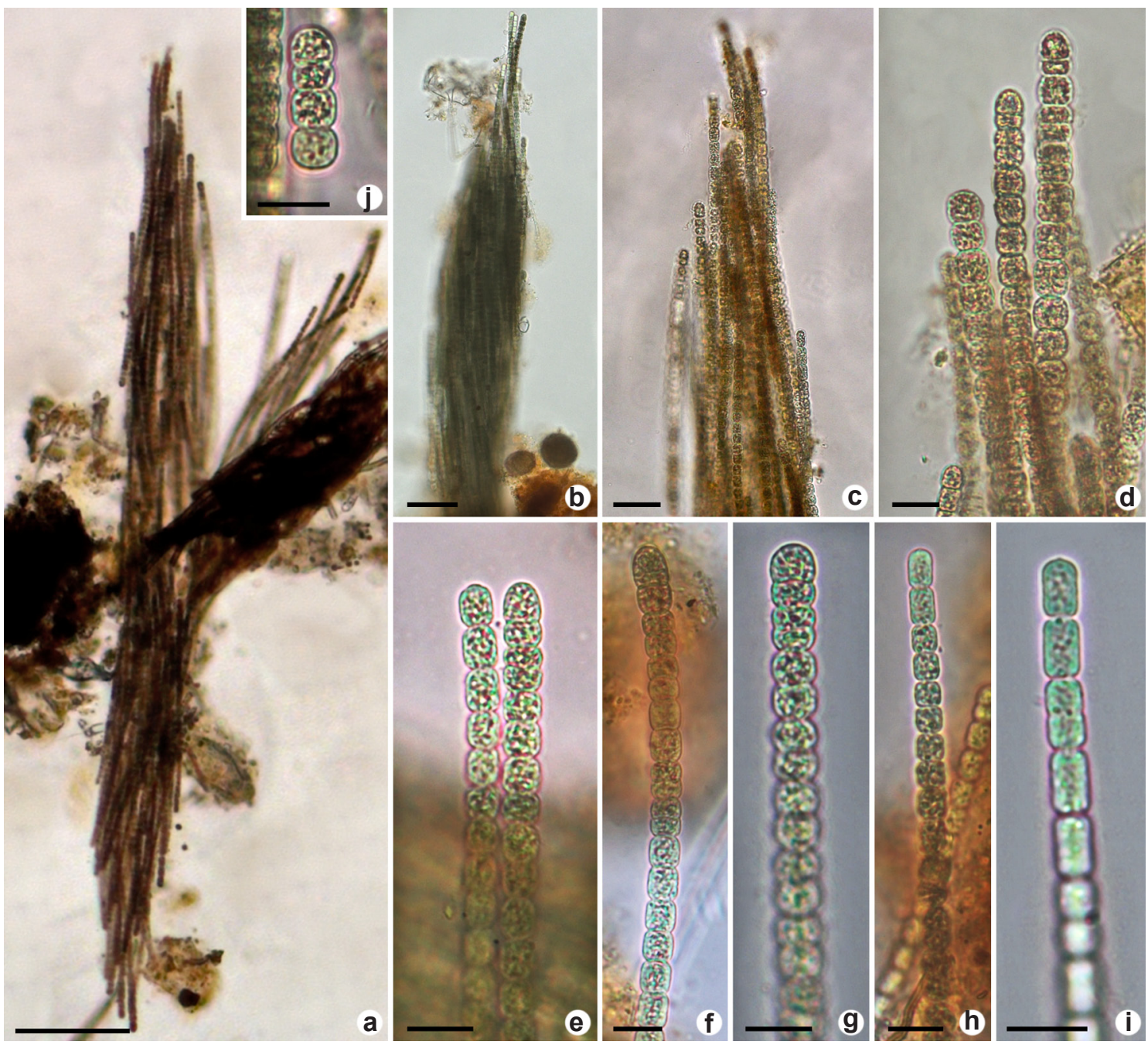

Figure 1 - Trichodesmium brasiliense - a-b. general aspect of fascicles; c-d. details of apex of fascicles; e-g. details of trichomes with rounded cells, gas vesicles and granules; h-i. details of smaller trichomes with elongated cells and uniform content; j. hormogonium. 
Table 1 - Comparison between the Brazilian material and the other Trichodesmium species from freshwaters.

\begin{tabular}{|c|c|c|c|c|c|c|}
\hline Trichodesmium & $\begin{array}{c}\text { Fascicle } \\
\text { dimensions }(\mu \mathrm{m})\end{array}$ & Trichomes & $\begin{array}{c}\text { Form of } \\
\text { cells }\end{array}$ & $\begin{array}{l}\text { Cell dimensions } \\
(\mu \mathrm{m})\end{array}$ & Apical cell & Distribution \\
\hline $\begin{array}{l}\text { T. iwanoffianum } \\
\text { Nygaard }\end{array}$ & $\begin{array}{l}50-100 \times \\
650-900\end{array}$ & $\begin{array}{l}\text { Straight } \\
\text { or slightly } \\
\text { curved, } \\
\text { cylindrical, } \\
\text { constricted }\end{array}$ & Short barrel & $7-8 \times 2-5$ & Hemispherical & $\begin{array}{l}\text { Tropical: } \\
\text { Sumatra, } \\
\text { Mozambique, } \\
\text { Caribbean, China, } \\
\text { Brazil }\end{array}$ \\
\hline T. lacustre Klebahn & --------- & $\begin{array}{l}\text { Straight, } \\
\text { attenuated, } \\
\text { constricted }\end{array}$ & Short barrel & $5-8 \times 3-6$ & $\begin{array}{l}\text { Cylindrical with } \\
\text { rounded apex, } \\
\text { rounded, or } \\
\text { hemispheric }\end{array}$ & $\begin{array}{l}\text { Temperate, } \\
\text { tropical: Europe, } \\
\text { USA, Burma, } \\
\text { India, China. }\end{array}$ \\
\hline T. brasiliense sp. nov. & $70-96 \times 868.5$ & $\begin{array}{l}\text { Straight, } \\
\text { cylindrical, } \\
\text { constricted }\end{array}$ & $\begin{array}{l}\text { Elongated to } \\
\text { barrel-shaped }\end{array}$ & $4.6-7.1 \times 4.9-7.4$ & $\begin{array}{l}\text { Hemispheric to } \\
\text { elongated }\end{array}$ & $\begin{array}{l}\text { Tropical and } \\
\text { subtropical: } \\
\text { Brazil }\end{array}$ \\
\hline
\end{tabular}

species in contrast to the cylindrical trichomes of $T$. brasiliense. Length/width rate together with trichome width are very important morphologic markers to the group of homocyted cyanobacteria, mainly for the Oscillatoriaceae and Microcoleaceae families (Komárek et al. 2014).Besides, the Brazilian material presents two types of trichomes inside the same fascicle: Figure 1e-g shows strongly constricted trichomes with roundedelongated cells and Figure 1h-i displays smaller and less constricted trichomes with barrel-shaped cells and some of them without gas vesicles and granules. These two types of trichomes in the same fascicle have never been described to other freshwater species. Considering that both types of trichomes are densely aggregated in the fascicle, it is possible to suppose that the smaller trichomes with some cells without gas vesicles and granules ("lighter") would be involved in nitrogen fixation, exactly as described by Bergman et al. (2013). According to these authors, this process is known to marine species of Trichodesmium to perform spatial fixation of nitrogen, which is much more efficient than temporal fixation.

Based on the statement of Komárek \& Anagnostidis (2005), the material mentioned by Smith $(1918,1920)$ as Trichodesmium lacustre does not correspond to the original description of this species because it does not present attenuated trichomes. Thus, Komárek \& Anagnostidis (2005) analyzed and identified the material just as Trichodesmium sp. Comparing the Brazilian population with the literature data, and with the additional material recovered from Brazilian Herbaria, we conclude that the specimens presented by Martins et al. (2012) as T. lacustre to South Brazil and those from Komárek \& KomárkováLegnerová (2007) referred as T. cf lacustre to São
Paulo state, are identical to our studied population and should be resigned into Trichodesmium brasiliense. As we could see, these materials also do not present attenuated trichomes, what is a quite common feature to T. lacustre. Also in the literature, the populations showed by Smith (1918, 1920) as Trichodesmium lacustre and by Tiffany (1937) and Prescott (1962) as Oscillatoria lacustris (Kleb.) Geitler, all of them from USA lakes, morphologically match the Brazilian material and certainly belong to the same species. However, as we have only morphological data obtained from literature and the ecology and geographic distance are different from Brazilian populations, we just highlight that these USA specimens could also belong to $T$. brasiliense. It is interesting that Prescott (1962) already pointed out his doubt about the identification of his material: "The specimens assigned here are enigmatic. The bundles of trichomes strongly suggest Trichodesmium because of their arrangement and lack of heterocysts. They are not like Trichodesmium lacustre Klebahn, however, in respect to the morphology of the apical cell which in that species is long and attenuated, but in our specimens it is short and rotund. There is scarcely enough evidence at present to justify giving a new name to the Wisconsin plant, but it is possible that subsequent study will establish it as a new freshwater species of Trichodesmium". According to Komárek \& Komárková-Legnerová (2007) "the identity of all described populations over the world up to now (including the Brazilian ones) should be revised".

The description of new species of cyanobacteria without genetic data is not very usual in current days. However, the accessibility to molecular information is not the same to all cyanobacterial groups, due to restrictions regarding 
pure culturing and single cell isolation from nature populations. So, in the cases of particular evidences, as morphoecological markers that distinguish populations which cannot be accessed by molecular techniques, the description of new taxa works as the recognition of the unknown biodiversity, which is proved to be vast to cyanobacteria (Nabout et al. 2013). T. brasiliense fits in this case by its singular morphological features, and differently from marine environments, in freshwater the populations of Trichodesmium showed to be very small. Summarizing, we are describing a new species of Trichodesmium, named T. brasiliense, which occurs in lakes from South America, encompassing tropical and subtropical regions.

\section{Acknowledgments}

The authors want to thank FAPESP (process 2011/50054-4) for the financial support and WAG also thanks FAPESP for fellowship support (FAPESP 2012/16430-1). We are also deeply thankful to Dr. Jiři Komárek, from the Academy of Science of the Czech Republic, for his excellent comments on freshwater Trichodesmium.

\section{References}

Bergman B, Sandh G, Lin S, Larsson J \& Carpenter EJ (2013) Trichodesmium-a widespread marine cyanobacterium with unusual nitrogen fixation properties. FEMS microbiology reviews 37: 286302.

Capone DG, Burns JA, Montoya JP, Subramaniam A, Mahaffey C, Gunderson T, Michaels AF \& Carpenter EJ (2005) Nitrogen fixation by Trichodesmium spp.: An important source of new nitrogen to the tropical and subtropical North Atlantic Ocean. Global Biogeochemical Cycles 19.

Capone DG, Zehr JP, Paerl HW, Bergman B \& Carpenter EJ (1997) Trichodesmium, a globally significant marine cyanobacterium. Science 276: 1221-29.

Carpenter EJ (1983) Nitrogen fixation by marine Oscillatoria. Nitrogen in the marine environment: 65-104.

Detoni AMS, Costa LDF, Pacheco LA \& Yunes JS (2016) Toxic Trichodesmium bloom occurrence in the southwestern South Atlantic Ocean. Toxicon 110: 51-55.

Ehrenberg C (1830) Neue Beobachlungen über blutartige Erscheinungen in Aegypten, Arabien und Sibirien, nebst einer Uebersicht und Kritik der früher bekannnten. Annalen der Physik 94: 477-514.

Gomont MA (1892) Monographie des Oscillariées (Nostocacées homocystées). Annales des Sciences
Naturelles, Botanique, Série 7 15: 263-368, pls 6-14.

Jackson W, Carmichael W \& Carpenter E (2001) The paralytic shellfish toxins, N-sulfocarbamoyl and gonyautoxin, are the major neurotoxic factors associated with the bloom-forming Trichodesmium spp. Abstracts, Fifth International Conference on Toxic Cyanobacteria, Noosa Lakes.

Klebahn H (1895) Gasvacuolen, ein Bestandteil der Zellen der wasserblütebildenden Phycochromaceen. Flora 80: 241-82, pl. IV.

Komárek J \& Anagnostidis K (2005) Cyanoprokaryota 2. Teil Oscillatoriales. In: Büdel B, Krienitz L, Gärtner G \& Schagerl M (eds.) Süsswasserflora von Mitteleuropa. Elsevier Spektrum Akademischer Verlag, München. P. 759.

Komárek J, Kaštovský J, Mareš J \& Johansen, J.R. 2014. Taxonomic classification of cyanoprokaryotes (cyanobacterial genera) 2014, using a polyphasic approach. Preslia 86: 295-335.

Komárek, J. \& Komárková-Legnerová, J. 2007. Several rare freshwater planktic Cyanobacteria (Cyanoprokaryotes) from reservoirs in South America. Hoehnea 34: 49-58.

Kützing FT (1843) Phycologia generalis: oder Anatomie, Physiologie und Systemkunde der Tange. Brockhaus,

Long B \& Carmichael W (2003) Marine cyanobacterial toxins. In: Hallegraeff GM, Anderson DM, Cembella AD \& Enevoldsen HO (eds.) Manual on harmful marine microalgae. Unesco, Paris. Pp. 279-96.

Martins MD, Branco LHZ \& Werner VR (2012) Cyanobacteria from coastal lagoons in southern Brazil: non-heterocytous filamentous organisms. Brazilian journal of botany 35: 325-38.

McNeill J, Barrie F, Buck W, Demoulin V, Greuter W, Hawksworth D, Herendeen P, Knapp S, Marhold K \& Prado J (2012) International code of nomenclature for algae, fungi and plants. Regnum vegetabile. Vol. 154. Koeltz Scientific Books, Koenigstein. 240p

Nabout JC, Silva Rocha B, Carneiro FM \& Sant'Anna CL (2013) How many species of Cyanobacteria are there? Using a discovery curve to predict the species number. Biodiversity and conservation 22: 2907-18.

Orcutt K, Rasmussen U, Webb EA, Waterbury JB, Gundersen K \& Bergman B (2002) Characterization of Trichodesmium spp. by genetic techniques. Applied and environmental microbiology 68: 2236-45.

Prescott GW (1962) Algae of the western Great Lakes area. $2^{\text {nd }}$ ed. Wm.C. Brown, Dubuque. 977 p.

Shaw G, Poon K, Codd G, O'Neil J, Lam P, Chong M, Davis B, Eaglesham G \& Moore M (2001) The 
presence of microcystin-like compounds in blooms of the marine cyanobacterium, Trichodesmium spp. Fifth International Conference on Toxic Cyanobacteria, Noosa. CSIRO, Canberra. P. 1.

Smith GM (1918) A second list of algae found in Wisconsin lakes. Transactions of the Wisconsin Acadademy of Science, Arts and Letters 19: 614-54. Smith GM (1920) Phytoplankton of the inland lakes of Wisconsin. Part I: Myxophyceae, Phaeophyceae,
Heterokonteae, and Chlorophyceae exclusive of the Desmidiaceae. Bulletin of the Wisconsin Geological and Natural History Survey 57: 1-243.

Suvapepun S (1992) Trichodesmium blooms in the Gulf of Thailand. Marine pelagic cyanobacteria: Trichodesmium and other diazotrophs. Springer, Dordrecht. Pp. 343-48.

Tiffany LH (1937) The filamentous algae of the west end of Lake Erie. American Midland Naturalist 18: 911-51. 